\title{
Seed Treatment Using Pre-infiltration and Biocontrol Agents to Reduce Damping-off of Corn Caused by Species of Pythium and Fusarium
}

\author{
W. Mao, R. D. Lumsden, J. A. Lewis, and P. K. Hebbar, Biocontrol of Plant Diseases Laboratory, USDA-ARS, \\ Beltsville, MD 20705
}

\begin{abstract}
Mao, W., Lumsden, R. D., Lewis, J. A., and Hebbar, P. K. 1998. Seed treatment using pre-infiltration and biocontrol agents to reduce damping-off of corn caused by species of Pythium and Fusarium. Plant Dis. 82:294-299.

Bioassays were conducted in a greenhouse at $18^{\circ} \mathrm{C}$ to determine the effectiveness of a seed treatment used in combination with biocontrol agents for the reduction of corn damping-off caused by species of Pythium and Fusarium. Corn seeds were infiltrated with tap water, drained, air-dried, and then coated with biomass of an antagonistic fungus, Gliocladium virens isolate Gl-3, or an antagonistic bacterium, Burkholderia cepacia isolates Bc-B or Bc-1, or a combination of Gl-3 with each of the bacterial isolates. A nonsterile field soil was infested with a combination of pathogens: Pythium ultimum, P. arrhenomanes, and Fusarium graminearum at 2 inoculum rates $(1 \times$ and $4 \times)$. Pre-infiltration enhanced $(P \leq 0.05)$ disease control with most treatments at both inoculum rates. Treatments with biocontrol agents alone or in combination, as well as the fungicide captan, effectively reduced the disease at a pathogen inoculum rate of $1 \times$, resulting in greater $(P \leq 0.05)$ seedling stands, plant height, and fresh weight, and lower $(P \leq$ $0.05)$ root rot severity compared with untreated seeds in infested soil. At a pathogen inoculum rate of $4 \times$, stands were lower $(P \leq 0.01)$ and root-rot severity was higher $(P \leq 0.01)$ compared to those at $1 \times$ for all treatments. Nevertheless, coating seeds with all biocontrol agents (alone or in combination), except with $\mathrm{Bc}-1$ alone, reduced disease $(P \leq 0.05)$ compared to untreated seeds in infested soil. At both inoculum rates of $1 \times$ and $4 \times$, coating seeds with Gl-3 + Bc-B was more effective $(P \leq 0.05)$ in disease control than any other treatment, resulting in stands, growth rate (plant height and fresh weight), and root rot severity similar to plants from untreated seeds in noninfested soil. In addition, when the exudate from a 2-h infiltration of corn seed was added to the seeds during seed coating, seedling stand was often lower and root rot severity was often higher than those from infiltrated seeds $(P \leq 0.05)$. These results indicated that the infiltration process removed certain exudates, including nutrients and/or stimulants (not detected in this study) that might be utilized by pathogens to initiate seed infection. A thin-layer chromatography (TLC) profile of the exudates showed the presence of eight amino acids and three major carbohydrates.
\end{abstract}

Damping-off of corn caused by Pythium spp. and Fusarium spp. is one of the most destructive diseases affecting seedling stands and yield $(6,23,25,31,33)$. The major strategies for disease management involve the use of pesticides and agricultural practices such as crop rotation and irrigation $(31,33)$. However, the efficacy and environmental concerns, as well as pathogen resistance to some pesticides, have encouraged research into biological control

Corresponding author: W. Mao

E-mail:wmao@asrr.arsusda.gov

This work was funded by a Cooperative and Development Agreement (CRADA) between the Northrup King Seed Company, Golden Valley, MN and the Biocontrol of Plant Diseases Laboratory, USDA-ARS, Beltsville, MD.

Accepted for publication 11 November 1997.

Publication no. D-1998-1222-02R

This article is in the public domain and not copyrightable. It may be freely reprinted with customary crediting of the source. The American Phytopathological Society, 1998. as an alternative approach or supplement to pesticides for protection against crop diseases $(1,9,20,22,32)$. Although numerous bacteria and fungi with a broad spectrum of antifungal activities have been identified and intensively investigated in greenhouse and field experiments for protection of various crops $(2,3,7,14)$, few have been studied for control of soilborne diseases of corn $(6,13,23)$.

A major consideration for successful biocontrol is the application of effective antagonist(s) to the appropriate ecological niche at the proper time $(8,9,21,22)$. For field crops such as corn, soybean, wheat, and rice, seed treatment with biocontrol agents is one of the most suitable methods for biocontrol of soilborne pathogens in the spermosphere and rhizosphere $(7,9,13,20)$. This is particularly true if applied antagonists are able to proliferate sufficiently to colonize the germinating seeds and the developing roots $(7,13,16)$. Burkholderia cepacia strains are naturally present in large numbers associated with corn roots $(12,13)$. When used in seed treatment trials, these strains have the potential to colo- nize roots and produce antibiotics to protect against pathogens. Recently, the development of fermentor-produced fungal biomass (15) has improved seed treatment with fungal antagonists $(8,19,29)$. For example, isolates of Gliocladium virens and Trichoderma viride have been applied to field corn seeds for the reduction of $P y$ thium- and Fusarium-induced damping-off (23).

To increase the efficacy of antagonists, combined biological, chemical, and/or physiological seed treatments have been investigated $(6,19,36)$. For example, biopriming seeds of $s h 2$ sweet corn in association with an antagonist and/or a fungicide resulted in a higher germination rate, greater seedling vigor, and lower disease severity than when this combination was not used $(24,36,37)$. F. oxysporum and Pseudomonas fluorescens in combination, as a seed treatment, were used to suppress Fusarium wilt of tomato (19). A combined seed treatment of solid matrix priming with Enterobacter cloacae or Trichoderma spp. reduced Pythium-induced damping-off of cucumber and tomato, and enhanced seedling growth (10).

One of the mechanisms for biocontrol agents to protect seeds and roots from pathogens is competition for soluble substrates which contain carbon, nitrogen, iron, and other elements $(10,22)$. Previous studies showed that the severity of damping-off in sweet corn, bean, soybean, pea, and cucumber was directly related to the amount of seed exudation during seed germination $(6,26,27,30,34)$. Callan et al. (6) found that the high levels of nutrient exudation by $\operatorname{sh} 2$ corn seeds during seed germination significantly inhibited biocontrol agents applied to suppress the target pathogen Pythium spp. Nelson and Craft $(26,27)$ reported that seeds of crops which produced less exudate during germination were more effectively protected from Pythium spp. and Fusarium spp. by E. cloacae than those which released abundant exudate.

In this paper, a seed treatment was examined using biocontrol agents, alone or in combination, applied to field corn seeds infiltrated with water and then dried to reduce damping-off caused by species of Pythium and Fusarium. The specific hypotheses were: (i) a combination of a fungal and a bacterial antagonist applied to corn seeds will increase the extent of disease suppression, and (ii) an infiltration 
treatment will reduce pathogen activity during seed infection by reducing the quantity of soluble substrates in or around the seed coat of corn.

\section{MATERIALS AND METHODS}

Microbial cultures and soil. The biocontrol fungus used in these studies was Gliocladium virens (= Trichoderma virens) Miller, Giddens, and Foster, isolate Gl-3, from the collection of the Biocontrol of Plant Diseases Laboratory. The bacteria used were Burkholderia cepacia (= Pseudomonas cepacia; 38) isolates $\mathrm{Bc}-\mathrm{B}$ (provided by Stine Seed Company, Adel, IA) and Bc-1 (isolated from a corn root in Beltsville, Maryland). The pathogens $F$. graminearum Schwabe and Pythium arrhenomanes Drechs. were isolated from a corn field soil in Beltsville, Maryland. $P$. ultimum Trow. was provided by D. E. Mathre, Montana State University. The pathogen isolates, G. virens Gl-3, and the bacterial isolates were grown on potato dextrose agar (PDA; Difco Laboratories, Detroit) at $24^{\circ} \mathrm{C}$ and maintained at $-80^{\circ} \mathrm{C}$ in a $50 \%$ solution of glycerol. A loamy sand soil which was collected from a corn field in Beltsville, $\mathrm{pH} 6.0$ to 6.5, was used in all studies.

Preparation of inocula. Biomass (inoculum) of $G$. virens isolate Gl-3 was produced in a molasses yeast medium in liquid fermentation for 10 days (29). The biomass was filtered on muslin, air-dried overnight in a transfer hood, milled to pass a $425-\mu \mathrm{m}$ screen, and stored at $4{ }^{\circ} \mathrm{C}$. The biomass of $G$. virens Gl-3 consisted mostly of chlamydospores, and propagule counts were greater than $10^{6} \mathrm{CFU} / \mathrm{g}$ as determined with a semi-selective medium (28). Biomass of each bacterium was prepared in 250-ml Erlenmeyer flasks containing 100 $\mathrm{ml}$ tryptic soy broth (TSB; Difco Laboratories). The flasks were placed on a rotary shaker $(120 \mathrm{rpm})$ for $48 \mathrm{~h}$ at $23 \pm 2{ }^{\circ} \mathrm{C}$. The cultures were then mixed with Nitragin Sterile peat (LiphaTech, Milwaukee, WI) so that $100 \mathrm{~g}$ peat was added to $100 \mathrm{ml}$ bacterial suspension $(1: 1, \mathrm{wt} / \mathrm{vol})$ and maintained as a slurry at $4{ }^{\circ} \mathrm{C}$ for no more than 7 days before use. The bacterial slurry contained $10^{9}$ to $10^{10} \mathrm{CFU} / \mathrm{g}$ as determined on a selective medium (4).

Pythium spp. were grown in foil-covered polypropylene flats ( 12 by 23 by $45 \mathrm{~cm}$ ) on a semi-solid medium which consisted of 600 ml (200 g) Redi-Earth 3 CP (GraceSierra, Milpitas, CA), $330 \mathrm{ml} 60 \%$ V8 juice (Campbell Soup Company, Camden, $\mathrm{NJ}), 10 \mathrm{~g}$ potato dextrose broth powder (Difco Laboratories), and $0.6 \mathrm{~g} \mathrm{CaCO}_{3}$. Flats containing the medium were autoclaved for $1 \mathrm{~h}$ on each of two consecutive days. The medium was inoculated with PDA disks (1-cm diameter) of the isolates, and incubated for 2 weeks at $23 \pm 2^{\circ} \mathrm{C}$. The inocula contained approximately $10^{5}$ $\mathrm{CFU} / \mathrm{g}$ as determined by the most probable number (MPN) assay (11). F. graminearum was cultured on a semi-solid wheat bran and water $(1: 1 \mathrm{wt} / \mathrm{wt})$ medium which was autoclaved on two consecutive days. The medium was inoculated and incubated for 10 days at $23 \pm 2{ }^{\circ} \mathrm{C}$. After incubation, the inoculum was air-dried for 3 days and milled in a blender to pass a $3.36 \mathrm{~mm}$ screen. The inoculum contained $10^{4}$ to $10^{5}$ $\mathrm{CFU} / \mathrm{g}$ as determined by serial dilution on a peptone pentachloronitrobenzene (PCNB) medium (5).

Seed treatments. Untreated and captantreated corn seeds, hybrid N 6330 provided by Northrup King Corporation, Minneapolis, Minnesota, were used in the studies. A 100-g sample of non-treated corn seed was placed in a $400-\mathrm{ml}$ beaker with $200 \mathrm{ml}$ tap water and infiltrated under vacuum in a desiccator for $2 \mathrm{~h}$. The infiltrated seeds were separated from the residual liquid, rinsed lightly with tap water for $1 \mathrm{~min}$, placed on a tray, and air-dried for $10 \mathrm{~h}$ in a fume hood. The infiltration solutions were stored in a freezer $\left(-5^{\circ} \mathrm{C}\right)$ before use. The moisture content of the seed before infiltration was 9 to $10.5 \%$, and was less than $12 \%$ after infiltration and air-drying.

For coating untreated seeds with bacterial isolates $\mathrm{Bc}-\mathrm{B}$ or $\mathrm{Bc}-1,10$-g samples of non-infiltrated or infiltrated seeds were mixed with $4.0 \mathrm{ml}$ aqueous solution (12\%) of Pelgel (LiphaTech) as a sticker, and 2.1 $\mathrm{g}$ slurry of each bacterial isolate was added. To coat seeds with G. virens Gl-3, 10-g samples of seeds (infiltrated and noninfiltrated) were mixed with $8 \mathrm{ml}$ sticker and $1.2 \mathrm{~g}$ biomass powder. For coating seeds with a combination of G1-3 and one of the bacterial isolates, the same rates of the slurry and biomass were added to $10-\mathrm{g}$ samples of seeds (infiltrated and non-infiltrated) with $6 \mathrm{ml}$ sticker. For untreated seeds, $2 \mathrm{~g}$ peat was added to $10 \mathrm{~g}$ seeds with $6 \mathrm{ml}$ sticker. For the exudate tests, sticker/exudate or sticker/water were prepared for coating infiltrated seeds with the biocontrol agent(s). In this approach, the exudate from a 2-h infiltration was used to make the sticker (Pelgel) solution. The seed, sticker, and biomass were mixed thoroughly, and the seeds were covered with sufficient dry Nitragin Sterile peat to form an even dry coating before storage at $4^{\circ} \mathrm{C}$ for no more than 5 days before planting. Seeds contained more than $10^{6}$ CFU/seed of Gl-3 propagules and more than $10^{8} \mathrm{CFU} / \mathrm{seed}$ of each of the bacterial isolates.

Bioassays. Pathogen inocula were applied to soil at a rate of $1.5 \mathrm{~g} F$. graminearum and $2.5 \mathrm{~g}$ each Pythium sp. per $150 \mathrm{~g}$ soil for an inoculum rate of $1 \times$, which was equivalent to approximately $1 \times$ $10^{3}$ and $3 \times 10^{3} \mathrm{CFU} / \mathrm{g}$ soil for $F$. graminearum and each of the Pythium spp., respectively. For an inoculum rate of $4 \times$, four times the amount of each inoculum was added to the same amount of soil. The inoculum rate of $1 \times$ was also used to determine the effect of exudate with infiltrated seeds. The infested and noninfested soils were placed in 10-cm-diameter plastic pots and immediately planted with 3 seeds/ pot using treated or untreated corn seeds. The experimental design was a randomized complete block with 10 replicates per treatment, and both experiments were repeated once. Pots were maintained in a greenhouse at $18^{\circ} \mathrm{C}$ and watered daily for 18 days. After plants were harvested, seedling stand, plant height, plant fresh weight, and root-rot severity were evaluated. Root rot severity was estimated according to the percentage of discoloration, necrosis, and rotting on roots, with an index in which $1=$ $<2 \%$ of root area affected (healthy plants), $2=3$ to $30 \%$ (slight disease), $3=31$ to $60 \%$ (moderate disease), $4=61$ to $90 \%$ (severe disease), and $5=>91 \%$ (dead plants).

Analysis of seed infiltration exudates by thin-layer chromatography (TLC). Fluorescent silica-gel TLC plates LHPKD60A and LK6DF-60A (Whatman Inc. Clifton, NJ) were used to separate and detect amino acids and carbohydrates, respectively, in the infiltration exudates of corn seed. Filter-sterilized $(0.2 \mu \mathrm{m})$ seed exudates $(10 \mathrm{ml} / \mathrm{sample})$ were lyophilized at -60 to $-70^{\circ} \mathrm{C}$ for $36 \mathrm{~h}$ and resuspended

Table 1. Analysis of variances (ANOVA) to evaluate the effects of application of biocontrol agents ${ }^{\mathrm{W}}$ to corn seeds, rates of the pathogens ${ }^{\mathrm{x}}$ used to infest soil, and seed infiltration on seedling stands, root rot severity, plant height, and fresh weight

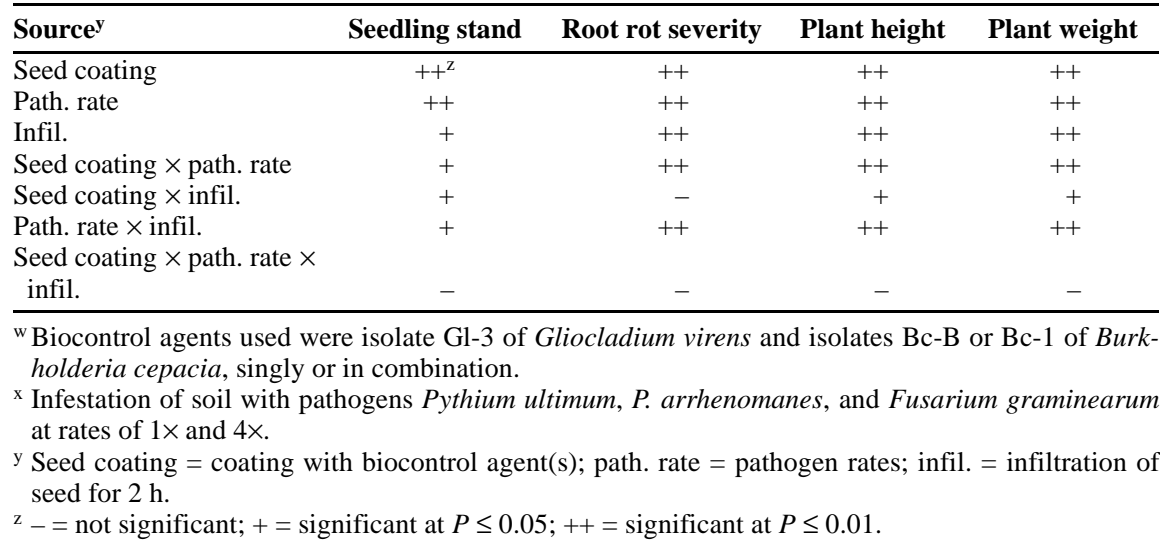


in $100 \mu \mathrm{l}$ sterile distilled water (SDW) before use. The TLC plates were first placed in an oven at $100^{\circ} \mathrm{C}$ for $10 \mathrm{~min}$, and then loaded with samples $(1,3$, or 5 $\mu 1 /$ spot) of various standards of amino acids or carbohydrates, water blanks, and concentrated exudates from a 2-h infiltration, and placed in a chamber to run for 2 to $2.5 \mathrm{~h}$, until the solvent front reached 15 $\mathrm{cm}$. The plates were developed using 1propanol:isopropanol (2-propanol):SDW (14:14:5, vol/vol/vol) for carbohydrates, or 1-propanol:SDW (85:15, vol/vol) for amino acids (17). Plates were air-dried in a hood for $45 \mathrm{~min}$ before they were sprayed with visualization reagents. To detect carbohydrates, plates were sprayed with naphthorescorcinol (0.2 g naphthorescorcinol in $100 \mathrm{ml} 99 \%$ EtOH and $20 \% \mathrm{H}_{2} \mathrm{SO}_{4}$ at $1: 1, \mathrm{vol} / \mathrm{vol})$. Plates were sprayed with $0.5 \%$ aqueous ninhydrin to detect amino acids. Amino acid plates were then airdried again for $10 \mathrm{~min}$ and examined under UV light. Carbohydrate plates were put in an oven at $100^{\circ} \mathrm{C}$ for $10 \mathrm{~min}$ and examined under fluorescent light.

Statistical analyses. Statistical analyses were conducted using SAS (version 6.08, SAS, Inc. Cary, NC) for all parameters of the two tests. Interactions between or among coating treatments, infiltration, and pathogen inoculum rates were determined. Duncan's multiple range test was used for mean separation $(P \leq 0.05)$ for all measurements. Since the results from repeated bioassays were similar $(P \geq 0.05)$, combined data from either the inoculum rate tests or the exudation tests are presented.

\section{RESULTS}

Inoculum rate test. Overall, seedling stand, plant height, fresh weight, and rootrot severity were significantly affected $(P$ $\leq 0.05$ ) by coating seeds with various biocontrol agents, rate of application of pathogens, and infiltration (Table 1). Interactions were also significant $(P \leq 0.05)$ between coating treatments and inoculum rates, infiltration and inoculum rates, and coating treatments and infiltration. Due to the interactions between these factors, analyses were also conducted individually based on an inoculum rate of $1 \times$ or $4 \times$ to determine the inter-relationships between coating treatments and infiltration.

In general, the infiltration treatment enhanced disease control for most treatments at a pathogen inoculum rate of either $1 \times$ or $4 \times$. When seeds were treated with most of the biocontrol agents, alone or in combination, infiltration significantly $(P \leq 0.05)$ increased stands (Fig. 1A and 2A), plant height (Fig. 1B and 2B), fresh weight (Fig. $1 \mathrm{C}$ and $2 \mathrm{C})$, and decreased $(P \leq 0.05)$ rootrot severities (Fig. 1D and 2D) compared to the same biocontrol treatments with non-infiltrated seeds.

With infiltrated or non-infiltrated seeds planted in soil at a pathogen inoculum rate of $1 \times$, seedling stands (Fig. 1A), plant height (Fig. 1B), and fresh weight (Fig.
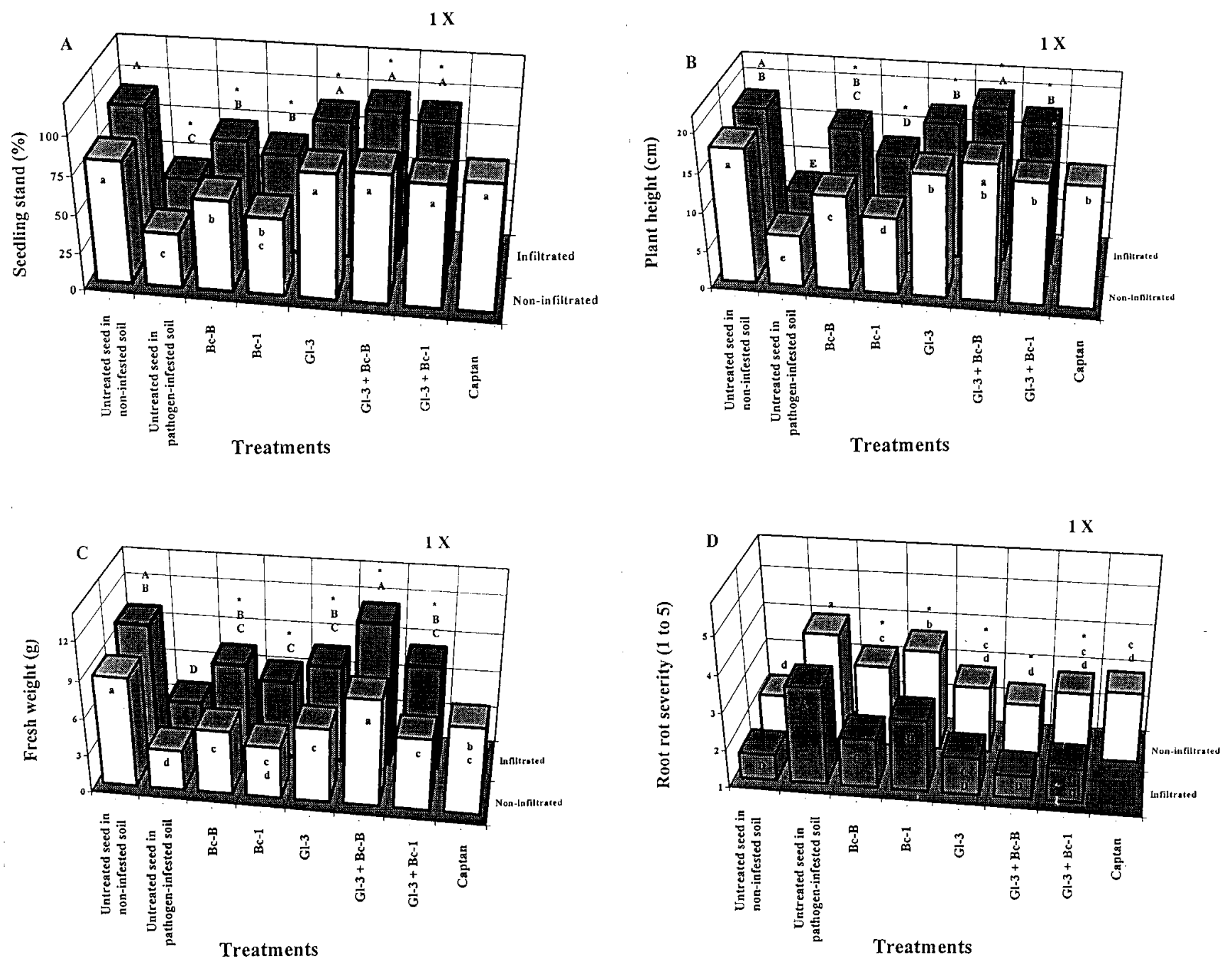

Fig. 1. Effect of seed treatment with Gliocladium virens (Gl-3), Burkholderia cepacia (Bc-B or Bc-1), and seed infiltration in soil infested with a combination of Pythium ultimum, P. arrhenomanes, and Fusarium graminearum at an inoculum rate of $1 \times$ on (A) seedling stand, (B) plant height, (C) plant weight, and (D) root rot severity, where $1=<2 \%$ root area affected (healthy plants) and $5=>91 \%$ root area affected (dead plants). Bioassays were conducted in a greenhouse at $18^{\circ} \mathrm{C}$ for 18 days and evaluation was made at harvest. According to Duncan's multiple range test $(P \leq 0.05)$, means with the same letter among the treatments are not significantly different from each other, but means between infiltrated and non-infiltrated seed with an asterisk (*) for the same coating treatment are significantly different from each other. 
1C) were significantly increased $(P \leq 0.05)$ in all treatments with the biocontrol agents, alone or in combination (except for Bc-1 alone with non-infiltrated seed) compared to those plants from untreated seeds in infested soil. Coating seeds with Gl-3 or $\mathrm{Gl}-3+\mathrm{Bc}-1$ resulted in stands similar to those of untreated seeds in noninfested soil (Fig. 1A), and in plant height and fresh weight comparable to those of seeds treated with captan (Fig. 1B and 1C). The combination coating with Gl-3 and Bc-B was the most effective treatment, resulting in stands, plant height, and fresh weight comparable to those from untreated seeds in noninfested soil, and significantly greater $(P \leq 0.05)$ for plant height and fresh weight than those with other biocontrol agents or captan.

In soil amended with pathogen inoculum at $4 \times$, stand, plant height, and fresh weight were significantly less $(P \leq 0.01)$ in all treatments compared to those at the lower rate of $1 \times$, although relative differences among treatments were similar. Coating seeds with the biocontrol agent(s), except Bc-1 alone, increased $(P \leq 0.05)$ stands (Fig. 2A), plant height (Fig. 2B), and fresh weight (Fig. 2C) compared to those plants from untreated seeds in infested soil, and resulted in comparable parameters as those from captan-treated seeds. Treatment with Gl-3 + Bc-B was the best treatment, resulting in stands comparable to those from untreated seeds in noninfested soil (Fig. 2A) and plant heights significantly greater $(P \leq 0.05)$ than that from captan-treated seeds (Fig. 2B).

With pathogen inoculum at $1 \times$, root-rot severities ranged from 1.5 to 2.5 among treatments with infiltrated seeds, and from 2.1 to 3.8 with non-infiltrated seeds (Fig. 1D). Coating infiltrated or non-infiltrated seeds with biocontrol agents, alone or in combination, significantly reduced root rot severities $(P \leq 0.05)$ compared to those from untreated seeds in infested soil. Coating seeds with Gl-3 alone, or in combination with $\mathrm{Bc}-\mathrm{B}$ or $\mathrm{Bc}-1$, resulted in similar root-rot severities as from captan- treated seeds or from untreated seeds in noninfested soil. Isolate $\mathrm{Bc}-1$ alone as a seed coating was not as effective $(P \leq$ 0.05 ) as other biocontrol agents on the reduction of root rot (Fig. 1D). With pathogen inoculum at $4 \times$, root-rot severities were greater $(P \leq 0.01)$ in all treatments than those at $1 \times$. However, coating infiltrated or non-infiltrated seeds with biocontrol agents, as well as captan, except with $\mathrm{Bc}-1$ alone, reduced $(P \leq 0.05)$ rootrot severities compared to those of the plants from untreated seeds in infested soil (Fig. 4D). Seeds treated with Gl-3 + Bc-B resulted in significantly lower $(P \leq 0.05)$ root-rot severities than those of the plants from any other treated seeds.

Exudation test. A qualitative analysis by a TLC plate profile was conducted to determine the amino acids and carbohydrates in the exudates of a 2-h seed infiltration. Eight amino acids (alanine, asparagine, glutamine, glutamic acid, proline, serine, valine, and phenylalanine) and three major carbohydrates (fructose, glu-
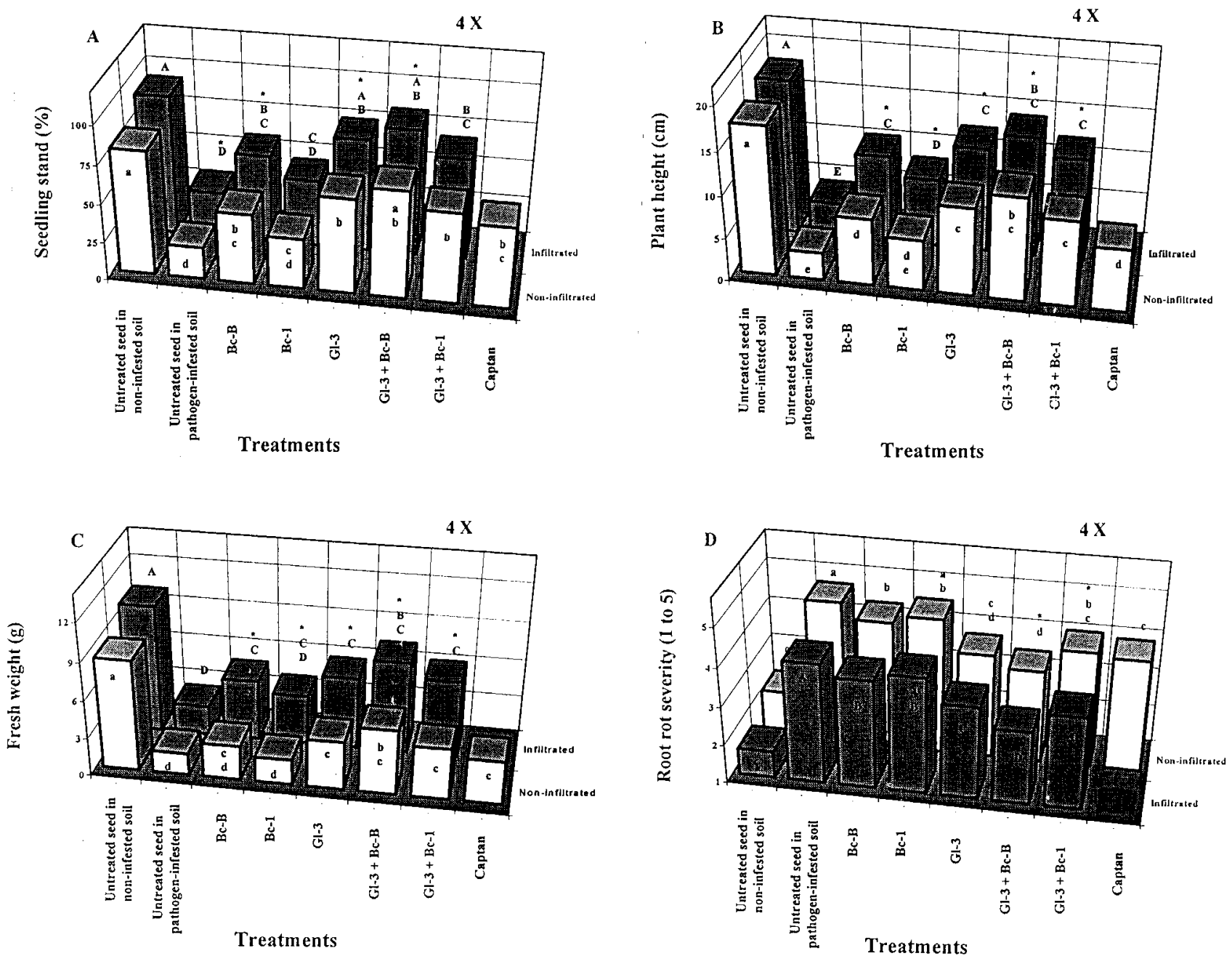

Fig. 2. Effect of seed treatment with Gliocladium virens (Gl-3), Burkholderia cepacia (Bc-B or Bc-1), and seed infiltration in soil infested with a combination of Pythium ultimum, P. arrhenomanes, and Fusarium graminearum at an inoculum rate of $4 \times$ on (A) seedling stand, (B) plant height, (C) plant weight, and (D) root rot severity, where $1=<2 \%$ root area affected (healthy plants) and $5=>91 \%$ root area affected (dead plants). Bioassays were conducted in a greenhouse at $18^{\circ} \mathrm{C}$ for 18 days and evaluation was made at harvest. According to Duncan's multiple range test $(P \leq 0.05)$, means with the same letter among the treatments are not significantly different from each other, but means between infiltrated and non-infiltrated seed with an asterisk (*) for the same coating treatment are significantly different from each other. 
cose, and sucrose) were found in the exudates.

When exudates from a 2-h seed infiltration were used to prepare the sticker for coating infiltrated seeds, there was more disease $(P \leq 0.05)$ in all treatments than when the sticker was prepared with water alone (Table 2). The stands and root-rot severities among treatments from the seeds prepared with the sticker/exudates were similar to those from non-infiltrated seeds in the inoculum rate tests.

\section{DISCUSSION}

One of the most important strategies used for biocontrol of soilborne plant pathogens is to protect the infection court (rhizosphere or spermosphere) of crops by biocontrol agents through competition for nutrients $(8,9,20,22)$. In this study, the treatment of seed infiltration significantly enhanced the activity of the biocontrol agents to suppress the disease, suggesting a role for water soluble nutrients and/or some non-nutrient elicitors (not detected in this study) within or surrounding the seed coat in disease development. Exudates as a result of infiltration were confirmed by TLC plate profiles, from which eight amino acids and three major carbohydrates were observed. It was also illustrated by the results that, when the exudates were added to infiltrated seeds during seed coating, significantly higher disease was observed. The process of seed infiltration is different from that of osmotic seed priming in that the former process is to remove some soluble molecules from the seed coat, whereas the latter is to induce the pre-germination of seed. Thus, after infiltration, the seed is re-dried and can be stored for a long time, but after osmotic priming the seed must be planted immediately.

The soluble molecules involved in stimulating soilborne fungal pathogens are thought to be primarily carbohydrates and amino acids (26). Seed and root infections do not occur without the release of such stimulatory molecules $(26,27)$. An infiltration treatment may increase the competition between pathogens and biocontrol agents by removing nutrients needed by the pathogens. The biocontrol agents have prior possession of the limited substrates so that stands could be established under adverse conditions $(27,30)$. The general beneficial interactions between infiltration and seed coating are reflected in the improvement of seedling stands and plant growth (height and fresh weight), and the reduction of root rot when compared with each component applied individually. Seed exudates, leached during germination, stimulated Pythium spp. and other microflora pathogenic to plants $(26,27)$. For example, Pythium spp. caused more seed rot among pea and soybean lines, which released more sugars and amino acids during germination than among those lines that released less (30).

Rhizosphere-competent biocontrol agents are effective because they protect not only the seed but also the seedling root $(1,9,13,22)$. Either $G$. virens or B. cepacia strains have shown the ability to colonize the rhizosphere when applied on seeds or as a soil treatment $(10,13)$. This study is one of the first in which both of these biocontrol agents have been applied together on corn seed to reduce Pythium and Fusarium damping-off. Other studies have included the use of strains of Gliocladium spp. and Burkholderia spp. individually or in combination with a fungicide for seed treatment, to suppress damping-off of several crops caused by species of Pythium $(3,10,23)$, Fusarium $(12,23)$, and other pathogens $(14,19,21)$. Results from the present study showed that coating seeds with Gl-3 and Bc-B provided the best disease control, especially under high disease pressure (inoculum rate of $4 \times$ ), often resulting in significantly greater seedling stands and growth rate, and less root-rot severity, than those from the seeds treated with either biocontrol agent alone or with captan. This indicates a beneficial compatible relationship between these two strains, since neither one inhibits the other when they were put together on a growth medium in an in vitro assay (data not shown). Application of these two antagonists together on corn seed might provide a broader antifungal activity than that achieved with either of the biocontrol agents alone. Chao et al. (7) reported that combinations of compatible bacteria and fungi can provide better control of seedand root-rotting pathogens than either used alone because they may avoid direct competition within the rhizosphere.

Results of the present study demonstrated that seed treatment with each biocontrol agent alone protected corn seeds and roots from the pathogens. Coating seeds with Gl-3 was more effective for disease reduction than coating seeds with $\mathrm{Bc}-\mathrm{B}$ or $\mathrm{Bc}-1$. These results are generally consistent with previous studies $(23,38)$, in which $B$. cepacia strains were not able to proliferate at a rate high enough to produce sufficient antibiotic metabolites (e.g., pyrrolnitrin) to effectively suppress the pathogens when soil temperature was below $18^{\circ} \mathrm{C}(23,35)$. However, G. virens strains might have a broad temperature range for their antifungal activity (23).

Competition between pathogens and beneficial microbes has been suggested to have a significant impact on succession and composition of microbial communities of the rhizosphere and spermosphere $(1,8,9,22)$. Successful biological control of soilborne pathogens is dependent on the ability of antagonists to effectively protect the infection courts from pathogens. In this study, disease reduction was significantly less in all treatments when antagonisttreated seeds were planted in soil with an inoculum rate of $4 \times$ than when seeds were planted in soil with an inoculum rate of $1 \times$. This indicated that initial population density of either the pathogens or the biocontrol agents is one of the most important factors influencing successful competition for their establishment and proliferation in the rhizosphere and spermosphere $(9,22)$. The interactions between seed coating and inoculum rate on disease could be explained by the differences in the disease suppression abilities of the biocontrol agents used.

This seed treatment using infiltrated seeds with biocontrol agents provided effective protection against damping-off of corn incited by pathogenic species of $P y$ thium and Fusarium. Application of this technology may be of interest and value to

Table 2. Effect of seed treatment with Gliocladium virens (Gl-3), Burkholderia cepacia (Bc-B, Bc-1), and sticker (Pelgel), prepared with water or infiltration exudate, on seedling stand and root rot severity

\begin{tabular}{|c|c|c|c|c|}
\hline \multirow[b]{2}{*}{ Treatments } & \multicolumn{2}{|c|}{ Seedling stand $(\%)$} & \multicolumn{2}{|c|}{ Root rot severity (1 to 5) } \\
\hline & Sticker/exudate & Sticker/water & Sticker/exudate & Sticker/water \\
\hline Untreated seed in non-infested soil & $86 \mathrm{~A}^{\mathrm{z}}$ & $91 \mathrm{AB}$ & $2.11 \mathrm{D}$ & $1.90 \mathrm{D}$ \\
\hline Untreated seed in pathogen-infested soil & $43 \mathrm{D}$ & $50 \mathrm{D}$ & $4.48 \mathrm{~A}$ & $4.22 \mathrm{~A}$ \\
\hline $\mathrm{Bc}-\mathrm{B}$ & $66 \mathrm{CD}$ & $84 \mathrm{~B} *$ & $3.44 \mathrm{BC}$ & $2.96 \mathrm{BC} *$ \\
\hline Bc-1 & $56 \mathrm{CD}$ & $64 \mathrm{C}$ & $3.61 \mathrm{~B}$ & $3.38 \mathrm{~B}$ \\
\hline Gl-3 & $80 \mathrm{AB}$ & $100 \mathrm{~A}^{*}$ & $3.09 \mathrm{BC}$ & $2.63 \mathrm{C}^{*}$ \\
\hline $\mathrm{Gl}-3+\mathrm{Bc}-\mathrm{B}$ & $86 \mathrm{~A}$ & $100 \mathrm{~A}^{*}$ & $2.74 \mathrm{CD}$ & $2.28 \mathrm{CD}^{*}$ \\
\hline $\mathrm{Gl}-3+\mathrm{Bc}-1$ & $77 \mathrm{AB}$ & $94 \mathrm{AB}^{*}$ & $2.94 \mathrm{C}$ & $2.55 \mathrm{CD} *$ \\
\hline
\end{tabular}

${ }^{y}$ Index of root rot: $1=<2 \%$ of root area affected (healthy plants), $2=3$ to $30 \%$ (slight disease), $3=31$ to $60 \%$ (moderate disease), $4=61$ to $90 \%$ (severe disease), and $5=>91 \%$ (dead plants).

${ }^{z}$ According to Duncan's multiple range test $(P \leq 0.05)$, means in each column with the same letter are not significantly different from each other, but means between sticker/exudate and sticker/water in each row with an asterisk $(*)$ are significantly different from each other. 
the corn seed industry and farmers to reduce the use of chemical fungicides. Moreover, adaptation of this system to other large-acreage crop seeds suggests further potential for the implementation of biological control.

\section{ACKNOWLEDGMENTS}

We thank K. Stanley, C. McCarthy, and H. Chow for their technical assistance, and R. Yucel for her help on amino acid TLC profile.

\section{LITERATURE CITED}

1. Ahmad, J. S., and Baker, R. 1987. Rhizosphere competence of Trichoderma harzianum. Phytopathology 77:182-189.

2. Arima, K., Imanaka, H., Kousaka, M., and Tamura, G. 1964. Pyrrolnitrin, a new antibiotic substance produced by Pseudomonas. Agric. Biol. Chem. 28:575-576.

3. Bowers, J. H., and Parke, J. L. 1993. Epidemiology of Pythium damping-off and Aphanomyces root rot of peas after seed treatment with bacterial agents for biological control. Phytopathology 83:1466-1473.

4. Burbage, D. A., Sasser, M., and Lumsden, R. D. 1982. A medium selective for Pseudomonas cepacia. Phytopathology 72:706.

5. Burgess, L. W., and Liddell, C. M. 1983. Manual for Fusarium Research. University of Sydney, Sydney, Australia.

6. Callan, N. W., Mathre, D. E., and Miller, J. B. 1990. Bio-priming seed treatment for biological control of Pythium ultimum preemergence damping-off in $s h 2$ sweet corn. Plant Dis. 74:368-372.

7. Chao, W. L., Nelson, E. B., Harman, G. E., and Hoch, H. C. 1986. Colonization of the rhizosphere by biological control agents applied to seeds. Phytopathology 76:60-65.

8. Fravel, D. R., Connick, W. J., Jr., and Lewis, J. A. Formulation of microorganisms to control plant diseases. In: Formulation of Microbial Biopesticides, Beneficial Microorganisms and Nematodes. H. D. Burges, ed. Chapman and Hall, London. In Press.

9. Harman, G. E. 1992. Development and benefits of rhizosphere competent fungi for biological control of plant pathogens. J. Plant Nutr. 15:835-843.

10. Harman, G. E., and Taylor, A. G. 1988. Improved seedling performance by integration of biological control agents at favorable $\mathrm{pH}$ levels with solid matrix priming. Phytopathology 78:520-525.

11. Harris, R. F., and Sommers, L. E. 1968. Platedilution frequency technique for assay of microbial ecology. Appl. Microbiol. 16:330-334.

12. Hebbar, P. K., Atkinson, D., Tucker, W., and Dart, P. J. 1992. Suppression of Fusarium moniliforme by maize root-associated Pseudomonas cepacia. Soil Biol. Biochem. 24:1009-1022.

13. Hebbar, P. K., Davey, A. G., Merrin, J., McLoughlin, T. J., and Dart, P. J. 1992. Pseu- domonas cepacia, a potential suppressor of maize soil-borne diseases-seed inoculation and maize root colonization. Soil Biol. Biochem. 24:999-1007.

14. Howell, C. R., and Stipanovic, R. D. 1995. Mechanisms in the biocontrol of Rhizoctonia solani-induced cotton seedling disease by Gliocladium virens: antibiosis. Phytopathology 85:469-472.

15. Jackson, M. A., and Schisler, D. A. 1995. Liquid culture production of microsclerotia of Colletotrichum truncatum for use as bioherbicidal propagules. Mycol. Res. 99:879-884.

16. King, E. B., and Parke, J. L. 1993. Biocontrol of Aphanomyces root rot and Pythium damping-off by Pseudomonas cepacia AMMD on four pea cultivars. Plant Dis. 77:1185-1188.

17. Kirchner, J. G. 1978. Thin-layer chromatography. Techniques of Chemistry, Second Edition, Vol. XIV. A. Weissberger, ed. John Wiley \& Son, New York.

18. Kloepper, J. W., Lifshitz, R., and Zablotowicz, R. M. 1989. Free-living bacterial inocula for enhancing crop productivity. Trends Biotechnol. 7:39-44.

19. Lemanceau, P., and Alabouvette, C. 1991. Biological control of Fusarium diseases by fluorescent Pseudomonas and non-pathogenic Fusarium. Crop Prot. 10:279-286.

20. Lewis, J. A. 1991. Formulation and delivery systems of biocontrol agents with emphasis on fungi. Pages 279-287 in: The Rhizosphere and Plant Growth. D. L. Keister. and P. B. Cregan, eds. Kluwer Academic Publishers, Netherlands.

21. Lewis, J. A., Fravel, D. R., Lumsden, R. D., and Shasha, B. S. 1995. Application of biocontrol fungi in granular formulations of pregelatinized starch-flour to control dampingoff diseases caused by Rhizoctonia solani. Biol. Control 5:397-404.

22. Lumsden, R. D., Lewis, J. A., and Fravel, D. R. 1995. Formulation and delivery of biocontrol agents for use against soilborne plant pathogen. Pages 166-182 in: Biorational Pest Control Agents Formulation and Delivery. F. R. Hall and J. W. Barry, eds. American Chemical Society, Washington, DC.

23. Mao, W., Lewis, J. A., Hebbar, P. K., and Lumsden, R. D. 1996. Seed treatment with a fungal or a bacterial antagonist for reducing corn damping-off caused by species of Pythium and Fusarium. Plant Dis. 81:450-454

24. Mathre, D. E., and Johnston, R. H. 1995. Combined biological and chemical seed treatments for control of two seedling diseases of $\operatorname{sh} 2$ sweet corn. Plant Dis. 79:11451148.

25. McGee, D. C. 1988. Diseases that are not seedborne or seed transmitted. Pages 100-103 in: Maize Diseases: A Reference Source for Seed Technologists, Part 3. American Phytopathological Society Press, St. Paul, MN.

26. Nelson, E. B. 1990. Exudate molecules initiating fungal responses to seeds and roots.
Plant Soil 129:61-73.

27. Nelson, E. B., and Craft, C. M. 1989. Comparative germination of culture-produced and plant-produced sporangia of Pythium ultimum in response to soluble seed exudates and exudate components. Phytopathology 79:10091013.

28. Papavizas, G. C., and Lumsden, R. D. 1982. Improved medium for isolation of Trichoderma spp. from soil. Plant Dis. 66:10191020.

29. Papavizas, G. C., Dunn, M. T., Lewis, J. A. and Beagle-Ristaino, J. 1984. Liquid fermentation technology for experimental production of biocontrol fungi. Phytopathology 74:11711175.

30. Parke, J. L., Rand, R. E., Joy, A. E., and King, E. B. 1991. Biological control of Pythium damping-off and Aphanomyces root rot of peas by application of Pseudomonas cepacia or P. fluorescens to seed. Plant Dis. 75:987992.

31. Rao, B., Schmitthenner, A. F., and Ellet, C. W. 1978. Prevalence and virulence of Pythium spp. associated with root rot of corn in poorly drained soil. Phytopathology 68:1557-1563.

32. Stephens, P. M., Crowley, J. J., and O'Connell, C. 1993. Selection of Pseudomonas strains inhibiting Pythium ultimum on sugar beet seeds in soil. Soil Biol. Biochem. 9:1283-1288

33. Sumner, D. R. 1990. Root disease, populations of soil fungi, and yield decline in continuous double-crop corn. Plant Dis. 74:9498.

34. Suslow, T. V., and Schroth, M. N. 1982. Rhizobacteria of sugar beets: effects of seed application and root colonization on yield. Phytopathology 72:199-206.

35. Upadhyay, R. S., Visintin, L., and Jayaswal, R. K. 1991. Environmental factors affecting the antagonism of Pseudomonas cepacia against Trichoderma viride. Can. J. Microbiol. 37:880-884.

36. Wilson, D. O., Jr., and Mohan, S. K. 1992. Effect of seed moisturization and fungicide treatment on final stand of low vigor Shrunken 2 sweet corn inbreds. J. Prod. Agric. 5:510-512.

37. Wilson, D. O., Jr., Mohan, S. K., Knott, E. A., and Shafii, B. 1993. Evaluation of fungicide seed treatments for Shrunken-2 "Supersweet" sweet corn. Plant Dis. 77:348-351.

38. Yabuchi, E., Kosako, Y., Oyaizu, H., Yano, H., Hasimoto, Y., Ezaki, T., and Arakawa, M. 1992. Proposal of Burkholderia gen. nov. and transfer of seven species of the Pseudomonas homology Group II to a new genus, with type species Burkholderia cepacia (Palleroni and Holmes, 1981) comb. nov. Microbiol. Immunol. 34:1251-1275.

39. Zablotowicz, R. M., Press, C. M., Lyng, N., Brown, G. L., and Kloepper, J. W. 1991 Compatibility of plant growth promoting rhizobacterial strains with agrichemicals applied to seed. Can. J. Microbiol. 38:45-50. 